\title{
RELATIONSHIP OF THE EATING BEHAVIOR FEATURES WITH ANTHROPOMETRIC INDICATORS AND ENERGY VALUE OF THE DIET IN YOUNG PEOPLE WITH NORMAL WEIGHT AND OVERWEIGHT
}

10.36740/WLek202012106

\author{
Khrystyna R. Boriak, Lyudmyla E. Vesnina \\ UKRAINIAN MEDICAL STOMATOLOGICAL ACADEMY, POLTAVA, UKRAINE
}

\begin{abstract}
The aim: Was to determine the relationship between the characteristics of eating behavior with anthropometric indicators and the energy value of the diet in young people with normal weight and overweight.

Materials and methods: We examined 84 subjects of both sexes aged from 18 to 25 years. We determined their body weight, height. According to the body mass index (BMI), we formed the following groups: the control group embraced 22 men and 22 women with a BMl of $18.50-24.99 \mathrm{~kg} / \mathrm{m}^{2}$, and the group of overweight subjects included 20 men and 20 women with a BMI of $25.00-29.99 \mathrm{~kg} / \mathrm{m}^{2}$. We evaluated the dietary regimen using the Dutch eating behavior questionnaire (DEBQ). The obtained data were processed statistically. Results: Changes in eating behavior were observed in $79.55 \%$ of subjects with normal weight and $90 \%$ of overweight subjects. In people with normal body weight, the restrictive type of eating behavior prevailed, in overweight subjects, the external and emotional types were observed.

Conclusions: The study established the formation of negative relationships of medium and high strength between the restrictive type of eating behavior and anthropometric indicators, as well as positive relationships of medium and high strength between indicators of emotional and external types with anthropometric indicators and energy value of diet in the subjects of both groups.
\end{abstract}

KEY WORDS: body mass index, overweight, eating behavior, eating disorders

Wiad Lek. 2020;73(12 p. I):2586-2590

\section{INTRODUCTION}

Nutrition is one of the most important environmental factors and it significantly affects the human body throughout life. Biocomponents of food, transforming in the process of metabolism into structural and functional elements of cells, provide physical and mental activity, adaptive capacity, forming an immune status that ensures normal health, affecting life expectancy, social and individual activity [1].

According to the World Health Organization (WHO), at the beginning of the 21 st century, about $50 \%$ of the adult population of the planet were overweight, and 25-30\% were obese [2]. Studies show that the prevalence of obesity worldwide has almost doubled in the last three and a half decades [3]. The urgency of the problem is determined by the fact that overweight and obesity today are so common that they affect the health of the population more than traditional health problems, including hunger and infectious diseases [2].

Currently, much attention is paid to the problem of nutrition and eating behavior. It has been established that overweight and obese people may have disorders in the psychological and mental spheres, which are accompanied by the formation of a pathological stereotype of nutrition [4]. This, in turn, changes the balance between energy consumption and expenditure, which is the main condition for maintaining normal body weight and energy metabolism, when consumption meets the needs for nutrients and energy in composition, quantity, the volume of physical activity.

Eating behavior is one of the main components of maintaining this balance. Eating disorders and dietary changes lead to an energy imbalance between calories consumed and expended by a man [5] and become one of the leading factors in the formation of obesity, which in turn leads to metabolic syndrome and the development of comorbidities. The relationship between the spread of eating disorders and eating status with chronic non-communicable diseases and metabolic disorders has been identified [6].

In recent decades, there has been a significant increase in the number of overweight and obese people, especially among children, adolescents, and young adults. Previous studies have shown that young overweight people have a higher energy value of the diet than people with normal weight [7].

\section{THE AIM}

The aim of this study was to determine the relationship between the characteristics of eating behavior with anthropometric indicators and the energy value of the diet in young people with normal weight and overweight. 
Table I. Indicators of anthropometric studies $(\mathrm{M} \pm \mathrm{m})$

\begin{tabular}{ccccc}
\hline & \multicolumn{2}{c}{ Men } & \multicolumn{2}{c}{ Women } \\
\cline { 2 - 5 } Indicators & $\begin{array}{c}\text { with normal body weight } \\
\mathbf{n = 2 2}\end{array}$ & $\begin{array}{c}\text { with overweight } \\
\mathbf{n = 2 0}\end{array}$ & $\begin{array}{c}\text { with normal body weight } \\
\mathbf{n = 2 2}\end{array}$ & $\begin{array}{c}\text { with overweight } \\
\mathbf{n = 2 0}\end{array}$ \\
\hline Age, years & $19.50 \pm 0.34$ & $19.93 \pm 0.44$ & $19.27 \pm 0.32$ & $19.25 \pm 0.34$ \\
\hline Height, $\mathrm{m}$ & $1.77 \pm 0.01$ & $1.78 \pm 0.01$ & $1.69 \pm 0.01$ & $1.67 \pm 0.01$ \\
\hline Body weight, $\mathrm{kg}$ & $68.31 \pm 1.71$ & $86.65 \pm 1.24^{*}$ & $62.09 \pm 1.00$ & $76.70 \pm 1.60^{*}$ \\
\hline BMl, $\mathrm{kg} / \mathrm{m}^{2}$ & $21.65 \pm 0.32$ & $27.09 \pm 0.28^{*}$ & $21.71 \pm 0.19$ & $27.28 \pm 0.23^{*}$ \\
\hline WC, $\mathrm{cm}$ & $75.90 \pm 1.19$ & $89.20 \pm 0.83^{*}$ & $69.90 \pm 0.70$ & $81.55 \pm 0.93^{*}$ \\
\hline TC, $\mathrm{cm}$ & $94.18 \pm 0.95$ & $105.15 \pm 0.92^{*}$ & $96.59 \pm 1.00$ & $107.80 \pm 0.97^{*}$ \\
\hline The ratio of WC/TC & $0.80 \pm 0.01$ & $0.84 \pm 0.01^{*}$ & $0.72 \pm 0.01$ & $0.75 \pm 0.01$ \\
\hline
\end{tabular}

Note: hereinafter in the tables:

* $-p<0.05$ as compared to subjects with normal body weight.

Table II. The structure of eating behavior according to the DEBQ questionnaire $(M \pm m)$

\begin{tabular}{ccccc}
\hline & \multicolumn{2}{c}{ Men } & Women \\
\cline { 2 - 5 } Indicators & $\begin{array}{c}\text { with normal body } \\
\text { weight } \\
\mathbf{n}=\mathbf{2 2}\end{array}$ & $\begin{array}{c}\text { with overweight } \\
\mathbf{n = 2 0}\end{array}$ & $\begin{array}{c}\text { with normal body } \\
\text { weight } \\
\mathbf{n}=\mathbf{2 2}\end{array}$ & $\begin{array}{c}\text { with overweight } \\
\mathbf{n = 2 0}\end{array}$ \\
\hline $\begin{array}{c}\text { Restrictive } \\
\text { type of eating behavior, points }\end{array}$ & $2.35 \pm 0.21$ & $1.86 \pm 0.44$ & $2.58 \pm 0.46$ \\
\hline Emotional type of eating behavior, points & $1.59 \pm 0.37$ & $1.84 \pm 0.41^{*}$ & $1.84 \pm 0.33$ & $2.41 \pm 0.22^{*}$ \\
\hline External type of eating behavior, points & $2.59 \pm 0.21$ & $3.14 \pm 0.29^{*}$ & $2.54 \pm 0.22$ & $3.12 \pm 0.26^{*}$ \\
\hline
\end{tabular}

\section{MATERIALS AND METHODS}

The study enrolled 84 men and women aged from 18 to 25 years. The study was authorized by the Commission on Bioethics of Ukrainian Medical Stomatological Academy. Informed consent to participate in the study was signed with each participant. The anamnesis data of the examined persons were entered into the observation record. The criterion for inclusion in the study was the absence of somatic pathology in the respondents.

The following anthropometric indicators were determined: height, body weight, waist circumference (WC), and thigh circumference (TC), the ratio of waist circumference to thigh circumference (WC/TC) [8]. To determine the body mass index (BMI), we used the formula: $\mathrm{BMI}=$ body weight $(\mathrm{kg}) /$ height $\left(\mathrm{m}^{2}\right)$ (WHO, 1998).

The distribution by groups was carried out according to the value of BMI: the control group consisted of 22 men and 22 women with a BMI of $18.50-24.99 \mathrm{~kg} / \mathrm{m}^{2}$, the group of overweight included 20 men and 20 women with a BMI of $25.00-29.99 \mathrm{~kg} / \mathrm{m}^{2}$.

We evaluated the dietary regimen using the Dutch eating behavior questionnaire (DEBQ) [9]. This questionnaire contains 33 questions, each of which has 5 answer options: "never", "occasionally", "sometimes", "often" and "very often". The results are evaluated on a 5-point scale, except for Question 31, which has inverse values. The obtained points are added and divided by the number of questions. Questions 1 to 10 constitute a scale of restrictive eating behavior, Questions 11 to 23 - a scale of emotional eating behavior, Questions 24 to 33 - a scale of external eating behavior. The average indicators of restrictive, emotional and external eating behavior are 2.4, 1.8 and 2.7 points, respectively [9].

We used STATISTICA 10.0 software package (StatSoft Inc., USA) for statistical processing of the results. The arithmetic mean $(\mathrm{M})$ and its error $(\mathrm{m})$ were determined. Correlation analysis was performed to assess the relationship between the values. Statistically significant data were considered at $\mathrm{p}<0.05$.

\section{RESULTS AND DISCUSSION}

According to anthropometric studies, we revealed an increase in body weight by $26.85 \%$, BMI by $25.13 \%$, WC by $17.52 \%$, TC by $11.65 \%$, the ratio of WC/TC by $5.0 \%$ in overweight men as compared to the control group $(p<0.05)$ (Table I ). In overweight women, we also found an increase in body weight by $23.53 \%$, BMI by $25.66 \%$, WC by $16.67 \%$, and TC by $11.60 \%$ as compared to the control group $(\mathrm{p}<0.05)$ (Table I).

Prior to this study, we had determined the percentage of body fat mass (\%BFM) in these individuals, using the method of calipometry [10]. We found that in overweight men, \%BFM was significantly higher by $93.73 \%$ (20.40 \pm 0.84 vs. $10.53 \pm 0.31$ in the control group), in overweight women, it was by $37.26 \%$ higher ( $28.22 \pm 0.55$ vs. $20.56 \pm$ 0.35 as compared to the control group) [11].

To assess eating behavior, we used the Dutch questionnaire DEBQ, which can be used to identify restrictive, emotional and external types of eating disorders [9]. 
According to the questionnaire, changes in eating behavior in the control group were observed in 35 (79.55\%) out of 44 respondents and in 36 (90\%) out of 40 overweight subjects.

We determined that in men with normal body weight, changes in eating behavior by restrictive type were observed in $9(40.91 \%)$ subjects, by emotional and external types - in 4 (18.18\%) subjects. The combination of emotional and external types of eating behavior was determined in $2(9.1 \%)$ subjects.

In women with normal body weight, changes in eating behavior by restrictive type were detected in 12 subjects (54.55\%), by emotional type - in 10 subjects (45.45\%), by external - in $5(22.73 \%)$ subjects. The combination of restrictive and emotional types of eating behavior was found in $3(13.64 \%)$ subjects, emotional and external - in $5(22.73 \%)$ subjects.

In overweight men, changes in eating behavior by restrictive type were found in $2(10 \%)$ subjects, by emotional type - in 10 (50\%) subjects, and by external - in 19 (95\%) subjects. The combination of restrictive and external types of eating behavior was observed in $2(10 \%)$ subjects, emotional and external - in $10(50 \%)$ subjects.

In overweight women, changes in eating behavior by emotional type were determined in $18(90 \%)$ subjects, by external - in $16(80 \%)$ subjects. A combination of emotional and external types of eating behavior was found in $15(75 \%)$ subjects.

A comparative evaluation of the results obtained by using the DEBQ questionnaire found that in overweight men, indicators of emotional and external types of eating behavior were higher by $15.72 \%$ and $21.24 \%$, respectively, than in men with normal body weight $(\mathrm{p}<0.05)$ (Table II).

In overweight women, the rates of emotional and external types of eating behavior were higher by $30.98 \%$ and $22.83 \% \%$, respectively, as compared to women with normal weight $(\mathrm{p}<0.05)$ (Table II).

The data obtained indicate that in both women and men with normal body weight, the restrictive type of eating behavior prevailed. In overweight subjects of both sexes, mostly external and emotional types of disorders were found as compared to individuals with normal body weight.

The energy value of the diet on weekdays and weekends in individuals of the studied groups was determined using the 24-hour dietary recall questionnaire [7].

It was found that the energy value of the diet of men with normal body weight on a working day was 2261.62 $\pm 69.82 \mathrm{kcal}$, in overweight men $-3297.11 \pm 89.04 \mathrm{kcal}$, in women with normal body weight $-1270.73 \pm 63.52$ $\mathrm{kcal}$, and in overweight women $-2080.34 \pm 115.28 \mathrm{kcal}$, respectively [7].

On a weekend, the energy value of the diet in men with normal body weight was $2465.42 \pm 52.08 \mathrm{kcal}$, in overweight men $-3852.36 \pm 139.69 \mathrm{kcal}$, in women with normal body weight $-1739.51 \pm 97,89 \mathrm{kcal}$, and in overweight women - of $2788.41 \pm 163.58 \mathrm{kcal}$, respectively [7].

We conducted a correlation analysis to determine the relationship between the characteristics of eating behavior with anthropometric indicators and the energy value of the diet.
In men with normal body weight, we detected the formation of negative correlations of medium and high strength between the restrictive type of eating behavior and body weight $(\mathrm{r}=-0.715, \mathrm{p}<0.05)$, BMI $(\mathrm{r}=-0.511$, $\mathrm{p}<0.05)$, WC $(\mathrm{r}=-0.735, \mathrm{p}<0.05)$, TC $(\mathrm{r}=-0.563$, $\mathrm{p}<0.05), \% B F M(r=-0.672, p<0.05)$. We also found the formation of positive relationships of medium strength between the emotional type of eating behavior and body weight $(\mathrm{r}=0.623, \mathrm{p}<0.05)$, BMI $(\mathrm{r}=0.435, \mathrm{p}<0.05)$, WC $(\mathrm{r}=0.678, \mathrm{p}<) 0.05)$, TC $(\mathrm{r}=0.456, \mathrm{p}<0.05)$. Furthermore, the study revealed the formation of positive relationships of medium strength between the external type of eating behavior and body weight $(\mathrm{r}=0.603, \mathrm{p}<0.05)$, BMI $(\mathrm{r}=0.451, \mathrm{p}<0.05), \mathrm{WC}(\mathrm{r}=0.651, \mathrm{p}<0), 05)$, as well as TC $(\mathrm{r}=0.515, \mathrm{p}<0.05)$.

In women with normal body weight, we detected the formation of negative links of medium strength between the restrictive type of eating behavior and BMI $(\mathrm{r}=-0.508$, $\mathrm{p}<0.05)$, BP $(\mathrm{r}=-0.540, \mathrm{p}<0.05)$. The study also found the formation of positive relationships of medium strength between the emotional type of eating behavior and body weight $(\mathrm{r}=0.493, \mathrm{p}<0.05)$, BMI $(\mathrm{r}=0.504, \mathrm{p}<0.05)$, WC $(\mathrm{r}=0.437, \mathrm{p}<)$ 0.05), \%BFM $(\mathrm{r}=0.428, \mathrm{p}<0.05)$. Moreover, we detected the formation of positive relationships of medium strength between the external type of eating behavior and body weight $(\mathrm{r}=0.508, \mathrm{p}<0.05)$, BMI $(\mathrm{r}=0.536, \mathrm{p}<0.05)$, WC $(\mathrm{r}=0.634, \mathrm{p}<0.05)$, and $\%$ BFM $(\mathrm{r}=0.473, \mathrm{p}<0.05)$.

In overweight men, we found the formation of negative correlations of medium and high strength between the restrictive type of eating behavior and body weight $(\mathrm{r}=-0.598, \mathrm{p}<0.05)$, BMI $(\mathrm{r}=-0.847, \mathrm{p}<0.05)$, WC $(r=-0.686, p<0.05)$. The formation of positive relationships of high and medium strength between the emotional type of eating behavior and BMI $(\mathrm{r}=0.676, \mathrm{p}<0.05)$, WC $(\mathrm{r}=0.461, \mathrm{p}<0.05)$, as well as between the emotional type of eating behavior and the indicator of the energy value of the diet on a weekend $(\mathrm{r}=0.497, \mathrm{p}<0.05)$ was observed. The study revealed the formation of positive relationships of medium and high strength between the external type of eating behavior and body weight $(\mathrm{r}=0.447, \mathrm{p}<0.05)$, BMI $(\mathrm{r}=0.937, \mathrm{p}<0.05)$, WC $(\mathrm{r}=0.476, \mathrm{p}<0.05)$ and TC $(\mathrm{r}=0.634, \mathrm{p}<0.05)$.

In overweight women, we found the formation of negative relationships of medium strength between the restrictive type of eating behavior and body weight $(\mathrm{r}=-0.556$, $\mathrm{p}<0.05)$, BMI $(\mathrm{r}=-0.688, \mathrm{p}<0.05)$ and TC $(\mathrm{r}=-0.686$, $\mathrm{p}<0.05$ ), positive relationships of medium strength between the emotional type of eating behavior and BMI $(\mathrm{r}=0.555, \mathrm{p}<0.05)$. The study also detected the formation of positive relationships of medium strength between the external type of eating behavior and body weight $(r=0.651$, $\mathrm{p}<0.05)$, BMI $(\mathrm{r}=0.674, \mathrm{p}<0.05), \mathrm{WC}(\mathrm{r}=0.469, \mathrm{p})<0.05)$ and TC $(\mathrm{r}=0.620, \mathrm{p}<0.05)$.

Thus, we identified changes in eating behavior in $79.55 \%$ of people with normal weight and $90 \%$ of overweight subjects. The structure of disorders in people with normal body weight was dominated by the restrictive type of eat- 
ing behavior, in overweight people - by the external and emotional types of eating behavior.

According to the study of a similar cohort of young people, eating disorders were found in $41.46 \%$ of subjects with normal body weight and $85.19 \%$ of overweight people. In subjects with normal weight, external and restrictive types of eating behavior predominated. Meanwhile, in overweight subjects, all three types of disorders were observed, with a predominance of the restrictive type and a significant percentage of disruptions by the external type [12].

According to L.V. Dudar and M.O. Ovdiy (2013), 37\% of people with normal body weight had eating disorders mainly of the emotional type. In the group of overweight subjects, eating disorders were identified in $89 \%$ of individuals with a significant predominance of the external type [4].

According to our research, people with normal body weight were dominated by the restrictive type of eating behavior. It is known that this type is characterized by dietary restrictions and the use of unsystematic strict diet, which can later be replaced by periods of overeating. During the periods of restriction, emotional instability, the so-called "dietary depression", can often occur. Further, its additional symptoms may be sleep disturbances, decreased self-esteem, agitation or inhibition, and difficulty concentrating [13].

Determining the relationship between the studied indicators showed that people with normal body weight with a predominance of the restrictive eating behavior form negative relationships of medium and high strength between this indicator and indicators of body weight, BMI, WC, TC.

In overweight individuals of both sexes, as well as in the control group, a similar trend was identified - the formation of negative relationships of medium and high strength in men and medium strength in women between the restrictive type and anthropometric indicators.

In overweight subjects, there was a predominance of external and emotional types of eating behavior. In the presence of the external type, the reaction usually occurs not to internal stimuli to food, such as hunger, filling the stomach, but to the external ones - food advertising, a table laid for dinner, the sight of food. Regardless of the feeling of satiety, such people are characterized by excessive food intake, which takes place in the company of guests, and as snacks on the street. The dominance of the external type was determined in young overweight men with a characteristic reaction mainly to external stimuli [14]. For this type of disorder, a directly proportional relationship with the level of stress is determined [15]. It was also determined that overweight and obese people with the external type of eating behavior have the highest energy value of the diet [6].

In the emotional type of eating behavior, the food stimuli are emotional discomfort, feelings of fear, loneliness, anxiety, resentment $[4,13]$. According to clinical studies, more than $60 \%$ of obese patients have the emotional type of eating disorder, the development of this type is a protective form against daily stress. 15-20\% of overweight people are diagnosed with one of the subtypes of the emotional type of eating disorders - compulsive overeating [16]. People with the emotional type of eating behavior are characterized by night eating syndrome - eating disorders, which are observed in about $9 \%$ of obese people when the consumption of more than $55 \%$ of the daily diet occurs in the evening $[6,16]$

The study of the relationship between external and emotional types of eating behavior with indicators of anthropometry and the energy value of the diet identified positive relationships. In people with normal body weight in the presence of emotional and external types of eating behavior, the formation of positive correlations of medium strength between these values and anthropometric indicators was observed.

It is important to note the formation of positive relationships of medium strength between indicators of emotional and external types of eating behavior and \%BFM in women with normal weight, while men in this group were characterized by the formation of negative relationships of medium strength between the restrictive type indicators and \%BFM.

In overweight men, we determined the formation of positive correlations of medium strength between the indicators of emotional type of eating behavior and correlations of medium and high strength between the indicator of the external type of eating behavior and anthropometric indicators. Positive relationships of medium strength were formed between the indicators of the emotional type of eating behavior and the energy value of the diet on a weekend. In women, there are positive correlations of medium strength between the indicators of emotional and external types of eating behavior and anthropometric indicators.

\section{CONCLUSIONS}

Changes in eating behavior were observed in $79.55 \%$ of people with normal weight and $90 \%$ of overweight subjects. In people with normal body weight, the restrictive type of eating behavior prevailed, in overweight people, the external and emotional types predominated.

The study found the formation of negative relationships of medium and high strength between the restrictive type of eating behavior and anthropometric indicators, as well as positive relationships of medium and high strength between the emotional and external types with anthropometric indicators and the energy value of the diet in subjects of both groups.

The formation of relationships of eating behavior with anthropometric indicators and the energy value of the diet requires a lifestyle modification at a young age. Reducing the energy value of the diet and increasing physical activity can be the basis for preventing the development of obesity and comorbidities.

\section{REFERENCES}

1. Simakhina H.O., Naumenko N.V. Kharchuvannya yak osnovnyy chynnyk zberezhennya stanu zdorov"ya naselennya [Nutrition as the main factor in maintaining the health of the population]. Problemy starinnya i dovholittya. 2016;25(2):204-214.(in Ukrainian). 
2. World Health Organization. Global Status Report on Noncommunicable Diseases 2014. Switzerland: 2014.

3. Arroyo-Johnson C., Mincey K.D. Obesity Epidemiology Worldwide. Gastroenterol Clin North Am. 2016;45(4):571-579. doi:10.1016/j. gtc.2016.07.012.

4. Dudar L.V., Ovdiy M.0. Rol' kharchovoyi povedinky ta rezhymu kharchuvannya v rozvytku nadlyshkovoyi masy tila v osib molodoho viku [The role of eating behavior and diet in the development of overweight in young people]. Suchasna hastroenterolohiya. 2013;4(72):31-35.(in Ukrainian).

5. Hill J.0., Wyatt H.R., Peters J.C. Energy balance and obesity. Circulation. 2012;126(1):126-132. doi:10.1161/CIRCULATIONAHA.111.087213.

6. Nikiforova Y.A.V. Vzayemozv"yazok kharchovoyi povedinky z metabolichnymy chynnykamy ryzyku [Relationship between eating behavior and metabolic risk factors]. Suchasna hastroenterolohiya. 2015;3(83):113-121. (in Ukrainian).

7. Vesnina L.E., Boriak K.H.R., Sokolenko V.M. Otsinka enerhetychnoyi tsinnosti kharchovoho ratsionu u osib molodoho viku z normal'noyu i pidvyshchenoyu masoyu tila [Assessment of the dietary energy intake of young people with normal weight and overweight]. Svit medytsyny ta biolohiyi. 2020;3(73):27-32. (in Ukrainian).

8. Martirosov E.G., Nikolaiev D.V., Rudniev S.H. Tekhnologii i metody opredeleniya sostava tela cheloveka [Technologies and methods for determining the composition of the human body]. Moskva. Nauka; 2006:248. (in Russian).

9. Van Strien T., Frijters J.E.R., Bergers G.P.A., Defares P.B. The Dutch Eating Behavior Questionnaire (DEBQ) for assessment of restrained, emotional, and external eating behavior. IJED. 1986; 5: 295-315.

10. Jackson A.S., Pollock M.L., Ward A. Generalized equations for predicting body density of women. Med. Sci. Sports Exerc. 1980; 12(3):175-182.

11. Boriak K.H.R., Vesnina L.E. Vyznachennya osoblyvostey vplyvu pidvyshchennya masy tila u molodomu vitsi na yakist' zhyttya [Determining the features of the impact of weight gain at a young age on quality of life]. Visnyk problem biolohiyi i medytsyny. 2019;2 (154): 390-394. (in Ukrainian).

12. Shevchenko Y.U.S., Vesnina L.E., Kaydashev I.P. Osoblyvosti kharchovoyi povedinky u osib z normal'noyu ta pidvyshchenoyu masoyu tila [Features of eating behavior in people with normal and overweight]. Fiziolohichnyy zhurnal.2015;61(3):51-58. (in Ukrainian).

13. Strien T. Causes of Emotional Eating and Matched Treatment of Obesity. Curr Diab Rep. 2018;18(6):1-8. doi:10.1007/s11892-018-1000-x.
14. Leonova Ye.N. Sotsial'no-psikhologicheskiye tipy pishchevogo povedeniya [Socio-psychological types of eating behavior]. Seriya filosofiya. Psikhologiya. Pedagogika. 2017;27(2):174-181. (in Russian).

15. Zhunisova M.B., Shalkharova Z.H.S., Shalkharova Z.H.N. et al. Psikhoemotsional'nyy stress kak prediktor tipa pishchevogo povedeniya v Kazakhstane [Psychoemotional stress as a predictor of the type of eating behavior in Kazakhstan]. Ekologiya cheloveka 2015;5:36-45. (in Russian).

16. Voznesenskaya T.G. Rasstroystva pishchevogo povedeniya pri ozhirenii i ikh korrektsiya [Eating disorders in obesity and their correction]. Farmateka. 2014;12:91-94. (in Russian).

The study was conducted in the framework of the planned research project of Ukrainian Medical Stomatological Academy "Comprehensive study of the pathogenetic role of the M1 and M2 macrophages subpopulations in the development of chronic obstructive pulmonary disease to develop and justify personalized therapy based on body weight", 2017-2019, state registration No. 0117 U005252.

\section{ORCID and contributionship:}

Khrystyna R. Boriak: 0000-0002-9048-6707 B, C, D

Lyudmyla E. Vesnina: 0000-0003-3068-6237 A, E, F

\section{Conflict of interest:}

The Authors declare no conflict of interest.

\section{CORRESPONDING AUTHOR Khrystyna R. Boriak}

Ukrainian Medical Stomatological Academy

23 Shevchenka Str., 36011 Poltava, Ukraine

tel: +380663235333

e-mail: kristinaboriak@gmail.com

Received: 11.08 .2020

Accepted: 20.11 .2020

A - Work concept and design, B - Data collection and analysis, C - Responsibility for statistical analysis, D-Writing the article, $\mathbf{E}$ - Critical review, $\mathbf{F}$ - Final approval of the article 